\title{
SØREN WICHMANN
}

\section{SPROG OG RUMLIG ORIENTERING I LIVSVERDENEN}

I den traditionelle, strukturalistiske sprogvidenskab antog man at sprogligt indhold udgør et lukket system defineret ved nogle indbyrdes oppositioner. Men der er i det mindste to tilfælde hvor dette synspunkt kommer til kort. For det første ser vi ofte i sprog eksempler på at en bestemt konceptualisering af verdens indretning allerede er indbygget $\mathrm{i}$ ordforråd eller grammatik. For det andet har vi også den omvendte situation at der er dele af sproget som helt må hente deres betydning fra den kontekst som udgøres af selve kommunikationssituationen, nemlig deiksis (typisk personlige pronominer, rumadverbier som her og der, relative tidsangivelser, m.v.). I begge tilfælde kan vi tale om ,,pragmatisk indhold“. Det lader til at eksistensen af sådanne pragmatiske sider af sproget gør at vi ikke kan bruge sproget adækvat uden at kende til verdens sociale og fysiske indretning. Hvis dette postulat er korrekt, er det også nødvendigt i en sprogbeskrivelse at tage hensyn til de givne sociale og fysiske rammer som sprogbrugeren befinder sig i.

I det følgende skal jeg forsøge at vise hvordan sproglige og etnografiske iagttagelser kan supplere hinanden i studiet af kulturelle forskelle. Iagttagelserne begrænser sig til den rumlige orientering i livsverdenen. Artiklen kan hverken blive en egentlig forskningsrapport eller en statusopgørelse over studier inden for området, men den kan prøve at være en smule af begge dele. Hovedparten af artiklen vil forsøge at pege på hvilke typer af iagttagelser man kunne gøre. Skulle læserens øjne stadig være på papiret ved afsnit 5 , vil de dér finde et lille udblik over videre litteratur inden for emnet.

\section{Gå ind på dit værelse med dig!}

Vi har på dansk et helt kompleks af faste udtryk som vi bruger når vi orienterer os i hjemmet: inde i stuen, inde på varelset, ude i køkkenet (/bryggerset/badevarelset), ude på toilettet(/altanen/gesimsen), oppe på loftet, nede $i$ kalderen. Disse udtryk er sammensat af en relativ retningsangiver (inde, ude, oppe, nede), en relativ positionsangiver $(i, p a ̊)$ og en stedsangiver (varelset, osv.). Læseren kan hurtigt overbevise sig selv om at det ikke er muligt at lave om på disse udtryk, de må altså anses for at være en del af det leksikalske inventar i dansk. Men samtidig angiver de en topologi for det danske hjem, hvor dele af det konceptualiseres som centrale, mens andre dele er perifere. Spaltningen i central/pe- 
rifer kommer naturligvis i stand ved retningsangiveren. Men den kvalificeres yderligere ved positionsangiveren. I den horisontale dimension kan positionsangiveren analyseres i forhold til en anden sproglig topologi, nemlig fastland/ø-modellen. Den position som mennesker indtager i forhold til fastland beskrives ved positionsangiveren $i$, mens vi befinder os på en $\emptyset$. Mere generelt kan man sige at på beskriver en position med hensyn til en isoleret entitet, mens $i$ beskriver en entitet som er integreret i en større helhed. Denne analyse kan vi herefter overføre til det danske hjem. I den vertikale dimension kunne gennemføre den samme analyse, hvilket jeg vælger her. Men vi kunne også argumentere for at positionsangiveren i den vertikale dimension opfører sig lidt anderledes, idet den ikke angiver isolation versus integration, men snarere en position som først bliver forståelig når vi indser at ,hjemmet“ også har eksterne konturer. Ved at ombytte „loft“ med ,hus“ og „,kælder“ med ,jord“" kan vi bruge positionsangiverne på og $i$ i stort set samme betydning. Brugen af positionsangiverne på og $i \mathrm{i}$ den vertikale dimension forudsætter altså, ifølge den alternative analyse, et metonymisk (navneombytnings-) forhold mellem hjemmet og dets eksterne topologi.

Ud fra disse betragninger kan vi opstille en model for hvordan nogle repræsentative dele af et typisk dansk hjem konceptualiseres sprogligt:

$\begin{array}{lll}\text { stue } & \text { central } & \text { integreret } \\ \text { værelse } & \text { central } & \text { isoleret } \\ \text { køkken } & \text { perifer } & \text { integreret } \\ \text { toilet } & \text { perifer } & \text { isoleret } \\ \text { kælder } & \text { nedre } & \text { integreret (?) } \\ \text { loft } & \emptyset v r e & \text { isoleret (?) }\end{array}$

(Hertil kan naturligvis tilføjes gesims, badeværelse, osv.). Indtil videre er analysen foregået på sprogets egne præmisser. Det lille semantiske system synes at være defineret ved nogle sproglige oppositioner alene. Hvad er det som alligevel får mig til at mene at dette er et skoleeksempel på at den klassiske, strukturelle analyse ikke er fyldestgørende? For at præcisere min position: der er dele af sproget hvor semantik ikke kan skelnes fra sprogbrug. Det er ikke umuligt at forestille sig den situation at en taler kom til at sige ude $\boldsymbol{i}$ to lettet i stedet for ude på toilettet. I en snæver, grammatisk forstand er der ikke tale om en fejl, men sproget ville være brugt forkert. Der er andre tilfælde hvor sprogfejl er af ren strukturel art, for eksempel i kongruens, hvor forbindelsen mellem to konstituenter afkræver brugen af en bestemt grammatisk kategori, her ental: *jeg har købt en nyt hus. Sprogfejl vidner altså om hvorvidt en given konstruktion har et mere eller mindre pragmatisk indhold.

For så vidt som en semantisk analyse umærkeligt glider over i analysen af sprogbrug, er det svært at trække grænsen for den sproglige beskrivelse, den er i princippet endeløs. I beskrivelsen af de danske udtryk som bruges når vi orienterer os sprogligt i hjemmet, er det, hvis vi skal formidle sproget til andre kulturer, påkrævet at tilføje en beskrivelse af hvordan de forskellige rum typisk ligger i forhold til hinanden. Den grundige forsker ville også spørge sig selv om, hvorvidt sproget afspejler tidligere tiders huskonstruktioner (var køkken og toilet tidligere separate konstruktioner?). Hun ville endvidere interviewe danskere om hvilke funktioner de forbinder med de enkelte rum, og måske nå frem til konklusioner som for eksempel den at danskeres praksis afspejler det sproglige 
udtryk, for så vidt som samtale/tv-konsumption er centrale, integrerede aktiviteter (stue), madlavning er en perifer, integreret aktivitet ( $\mathrm{k} \emptyset \mathrm{kken})$, arbejde/leg er en central, isoleret aktivitet (værelse) og defækering (toilet) er en perifer, isoleret aktivitet.

\section{Indenfor hos hopier og mayaer}

Den centrale skikkelse i udviklingen af ,language in culture“ som et sprogvidenskabeligt tema er Benjamin Lee Whorf, der skrev sine banebrydende og provokerende artikler overvejende i 30'erne. Som bekendt var det sproget hopi (New Mexico-Arizona) som han gang på gang vendte tilbage til i sine refleksioner over sproglig konceptualisering. Lad os se hvilke observationer han gør omkring hopi-hjemmet og dets sproglige gestaltning i sin artikel „Linguistic Factors in the Terminology of Hopi Architecture“ fra 1940 (genoptrykt i Whorf 1956:199-206). Det er slående, bemærker han, at der ikke er ét eneste udtryk for et indre, tredimensionelt rum, svarende til vores „værelse, rum, kammer, o.lign." Det tætteste man kan komme herpå er ?á'pà-v€ ? men dette ord er ikke et substantiv. Man kan altså blandt andet ikke sige „,mit ?á pà -v€ ?“, hvilket Whorf mener falder meget godt $\mathrm{i}$ tråd med at man i hopi-samfundet ikke kender til individuelt ejerskab af rum. Ordet tilhører egentlig klassen af „lokatorer", en slags adverbiel ordklasse som også

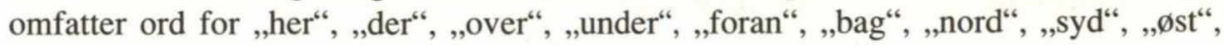
„,vest“ m.fl. - her i blandt en række stednavne. Suffikset $v \epsilon$ ? er et af flere som angiver relativ afstand.

Whorfs iagttagelser bliver bekræftet i en opfølgende undersøgelse af Malotki (1979:146-49), der videre redegør for hvordan man kan udtrykke sætninger som „, han gik gennem det inderste rum i vores hus “. Præciseringen af at det er det inderste rum der er tale om, sker ved at tilføje suffikser til roden ?á pà, som udtrykker stor relativ afstand. Forudsætningen for at meddelelsen er effektiv er naturligvis at modtageren er fuldt bekendt med hopi-huses typiske struktur - det består at et stort forrum og et-to mindre indre rum.

Sammenlignet med sproglige udtryk for det danske hjem har man på hopi altså en anderledes konceptualisering. Hvor vi beskriver de domestiske forhold som en færden og placering i forhold til nogle genstande, såsom „,køkken“, „stue“, og så videre, foretrækker man på hopi et mere generaliseret, relationelt begreb. Det er oplagt i denne forbindelse at spørge sig selv om hvorvidt forskellene i den sproglige konceptualisering af rummet modsvares af forskellige adfærdmønstre med hensyn til hjemmet. Whorf nævnte den forskel at ejerskab af værelser er ukendt for hopierne. Andre forskelle kunne have noget at gøre med hvorvidt og hvordan bestemte aktiviteter måtte være knyttet til bestemte steder i de respektive kulturer. Desværre kommer hverken Whorf, Malotki eller den etnografiske litteratur i øvrigt ind på dette spørgsmål.

Hanks (1990) er en omfattende undersøgelse af brugen af deiksis i yukatekisk maya (Yucatán, Mexico), som er inspireret af Bourdieus sociologi og af etnometodologi. Forfatteren forsøger at lave en teoretisk integration af studiet af sprogbrug og livssammenhænge. I denne undersøgelse finder vi, blandt meget andet, en detaljeret diskussion af den sproglige orientering i maya-hjemmet. Ligesom i hopi (og i øvrigt mange andre indianske sprog) skelnes der ikke terminologisk mellem typer af rum - når undtages distinktionen mellem ?ič nah ,i hus(et)“ og k'oób’ben „køkken“. ?Ič nah kan omfatte strukturer der omfatter lige fra to til otte rum og huser en eller flere familier. Den eneste 
måde at orientere sig sprogligt er ved brugen af deiksis. En taler som forklarede at hun forventede at der ville blive lagt nyt lergulv i det tilstødende rum den næste dag, sagde ved en lejlighed:

$\begin{array}{llllll}\text { saámalili } & \text { utokar } & \text { té } & i \check{c} & \text { nah } & o^{\prime} \\ \text { i morgen } & \text { tilfalder det } & \text { inde } & \mathrm{i} & \text { hus } & \text { der }\end{array}$

(Hanks 1990:326)

En sådan reference kan afkodes uden brug af ledsagende gestik fordi $o$ ' antyder en vis, ikke alt for fjern afstand til en synlig genstand, og fordi det kommunikationsfællesskab, som taler og lytter indgår $i$, er naturligt ledsaget af et fælles kendskab til de lokale (her domestiske) forhold.

I en interessant analyse redegør Hanks for at udtryk for ejerskab af rum kan komme i stand ved en sproglig segmentering der fuldkommen adækvat modsvarer virkelighedens på trods af at rum ikke kan benævnes, endsige besiddes sprogligt. En person ved navn Lol forklarer ham her hvordan han og hans familie oprindeligt købte den grund, hvor de to står og snakker, og hvordan de derefter lagde planer for konstruktionen af et hus:

Lol: kud'ó?ol e? ká tàal-ó?on bey way o?, derefter så kom vi her omkring ká $t$-?á?al e yan k-bèetk ump'eé nah té?el a? så sagde vi at vi ville bygge et hus lige her

WH: tú?uš hvor?

Lol: le way a? stedet lige her

WH: hač aha...

Lol: té? way-hàah... đ’óokok k-bèetk e plàano lige her - jaa... da vi havde lavet planen bey o? - miná? an ubloki, pero d'óok $k$-tukl ik $e$ ? som sagt - vi havde ikke blokkene, men vi havde besluttet lel a? - ump' eé pàarte teč $i$ ? ump' eé pàarte ten $i$ ? denneher, en del (er) til dig, en del til mig

(Hanks 1990:329; jeg har modificeret intonationsmarkeringen og andre detaljer).

I sin første ytring beskriver Lol hvordan han og hans familie opkøbte grunden og refererer til hele grunden med way ,her (inkluderende område)“ $+o$ ? ,relativ distance, inden for synsvidde“. Stedet hvor huset skulle bygges refereres til som té? $e l$,her" $+a$ ? „nær“. På Hanks' opfordring beskrives stedet alternativt som way ,her (inkluderende område)“ $+a$ ? „nær“. Men det afgørende punkt i samtalen er der hvor Lol begynder at snakke om opdelingen af grunden og starter med at bruge udtrykket té? way. Dette er en kombination af té? ,der (punkt nærved)“ og way „,her (inkluderende område)“. Hanks registrerede i løbet af sine ophold flere forekomster af brugen af denne besynderlige kombination skønt talerne generelt nægtede at man kunne sige sådan. Hans analyse (1990:48485) går nu ud på at udtrykket modspejler netop den type rumlig segmentering som også 
samtalen handler om. Udtrykket kan anskueliggøres som en større cirkel (way) med en mindre cirkel (té?) indeni. I samtalens videre forløb forklarer Lol hvordan det besluttedes at ét af ægteparrene (,dig“) skulle bebo den ene del af det projekterede hus og det andet ægtepar (,,mig“) den anden del. Bemærk at „mig“ og „dig“, i en sindrig persondeiktisk manøvre, er transponeret fra den aktuelle taler og lytter (Lol og Hanks) til hvert af de to ægtepar. Det, Lol beskriver, er en forhandling om inddeling af livsrummet i „frame spaces“ - med et begreb som Hanks har hentet hos Goffman (1981), og som løseligt kan oversættes med ,sociale og kommunikative handlingsradier eller -potentialer“.

Hanks' eksempel viser klart hvor central brugen af deiksis er i forhandlingen om og beskrivelsen af sociale rum. Den lingvistiske og den antropologiske undersøgelse er derfor uløseligt forbundne. Hvor vi i Whorfs overfladiske beskrivelse sidder tilbage med en fra forfatterens side intenderet følelse af at hopier, for så vidt som deres sprog jo er forskelligt fra vores, vist må tænke anderledes (og moralsk sundere) end vi gør, er det kun fordi hans beskrivelse er løsrevet fra et studium af social praksis. Når et sådant studium tilføjes, bliver det muligt at forstå de forskellige kulturer som et kompleks af faktorer, heriblandt sproglige, forankret i sociale interaktionsformer, og studiet af relativisme erstattes med et studium af kultur i egentlig forstand.

\section{Verden set gennem et egernøje}

I det ovenfor omtalte værk om deiksis i yukatetisk maya gør forfatteren også den observation at ,det gælder som en kulturel grundantagelse at alle besjælede væsner, også ånder, indehaver stabile steder hvorfra de lejlighedsvis bevæger sig" (Hanks 1990:344).

Det er sandsynligvis et træk ved alle kulturer at mange væsener og ting er karakteriseret, ja sommetider defineret, ved særlige spatiale tilhørsforhold. På et tidligt tidspunkt i vores egen kulturkreds blev denne opfattelse ligefrem udnyttet til at forklare det, som vi nu forstår som fysikkens ,kræafter": som bekendt ville Aristoteles forklare det, at en sten falder til jorden når man slipper den som et udslag af, at det er ved jorden at en sten rettelig hører til.

Et andet jordnært eksempel stammer fra et af mine feltarbejdsophold i Mexico. Jeg var blevet budt til bords og havde fået serveret en skål bønnesuppe. Men et lille barn fik væltet skålen ned på gulvet. Man kunne nu forvente at nogen kom og gjorde rent på gulvet, men det skete ikke (mens jeg var der). Det gik her op for mig at et gulv i mexikanske bondesamfund er delvis defineret som et naturligt sted for snavs - hvilket dog ikke betyder at man ikke jævnligt fejer det rent. Skønt eksemplet måske ikke er helt overbevisende - det er muligt at bønnesuppen fik lov at ligge for at det kunne tørre og således senere ville være lettere at feje væk - blev hypotesen dog bekræftet mange gange siden. Det er næsten givet at en mexikansk bonde, hvis du stiller din medbragte taske på gulvet, vil opfordre dig til at lægge den i en stol i stedet - igen fordi gulvet per definition er et snavset sted uanset graden af reel renhed. At der kan være en skjult kosmologi i måden at føre en støveklud på - henad eller nedad væggen er radikalt forskellige alternativer - er desværre noget som de færreste etnografier interesserer sig for.

Hvis det er givet at enhver kultur har sine bestemte definitioner af spatiale tilhørsforhold, skulle man så ikke forvente at en kategori så som at „høre hjemme“ versus ,ikke høre hjemme" var at finde indkodet som en grammatisk kategori? Dette er faktisk tilfæl- 
det i otomangue-sproget tlapanec, nærmere bestemt den variant, der tales i Azoyú, Guerrero, Mexico. Indholdet af kategorien, der i mindre omfang også er kendt fra andre sprog af otomangue-ætten, er siden Kuiper og Merrifield (1975) blevet benævnt som „base versus non-base“ (for en oversigt over senere bidrag til diskussionen se Merrifield 1992). Hvor tidligere studier kun har fundet kategorien brugt i forbindelse med en lille gruppe bevægelsesverber (typisk ,,at komme“, ,,at gå“, ,,at ankomme“), lader det nu til, i henhold til mine seneste feltarbejdsstudier af tlapanec, at kategorien, i det mindste i dette sprog, er mere udbredt.

I Wichmann (1993a:128-30) diskuterede jeg verbet ,,at ankomme“, som har to former alt efter om agenten ankommer til sin „,base“ eller sin ,non-base“. For tredje person singularis skelnes der yderligere mellem ankomst ,her" eller „der“" i forhold til talerens aktuelle fysiske lokation eller fikspunktet for en fortælling. I følgende eksempel fortæller en kvindelig taler om en mand som, når han besøger byen Azoyú, altid kommer og besøger hende fordi han føler sig som hendes søn:

\begin{tabular}{|c|c|c|}
\hline$g i^{l} y u^{2}$ & $n a k a^{2} n e^{1}$ & $g a^{2} h m u ?^{3}$ \\
\hline & han_ankommer_her_ved_non-base & hos_mig \\
\hline
\end{tabular}

Det er interessant at taleren under brugen af verbet naka $n e^{1}$ simultant anlægger to forskellige synspunkter. Den semantiske komponent „her“ udtrykker hendes eget synspunkt mens ,non-base“ anlægger besøgerens synspunkt.

Kategorien „base versus non-base“ er en morfologisk underkategori af iterativen; verber der udtrykker „base“ afledes altså morfologisk på samme måde som verber der udtrykker „gentagelse“ af forskellig art. Jeg har udførligt diskuteret iteration som en sproglig kategori i forhold til det ontologiske indhold af begrebet „gentagelse“ i Wichmann (1992). Denne diskussion vil jeg ikke tage op igen, men det er nødvendigt at nævne at de verber, der udtrykker base-kategorien, indgår i en større gruppe sammen med verber der implicerer ,,at gentage en handling“, ,helhed (versus del)“, ,,permanenthed“, ,,indtrædelse i den samme tilstand“, ,,distributiv“, mm. Samtidig er det værd at bemærke at alle de iterative verbers betydning kan beskrives relativt simpelt og monolitisk ved deres respektive måder at kombinere profileringen af handlingen eller landemærket (grunden) $\mathrm{i}$ handlingens spatiale dimension med simultaneitet eller ikke-simultaneitet $\mathrm{i}$ den temporale dimension. Denne måde at anskue semantik på er inspireret af Langacker (1987-1990) som igen har ladet sig inspirere af perceptionspsykologiens figur-grundbegreb. I verber der koder for „base“ er landemærket profileret og de to tilstande som verbet beskriver er ikke-simultane.

Under mit videre arbejde med iterativer på tlapanec er mit korpus af verber der koder for base-distinktionen blevet udvidet fra at omfatte en lille håndfuld bevægelsesverber til at omfatte ca. et halvt hundrede verber af ret forskellig art. Når jeg i det følgende citerer par af verber, kan den del af et par som koder for „,base“ genkendes på suffikset - $l i^{3}$, mens non-base-verberne ikke har dette suffiks i de former som citeres, nemlig tredje person.

Verber for transaktioner med genstande er også en type bevægelsesverber. Den implicitte bevægelse i verbet ,at bede om noget“ er fra giveren. Dette ses af at „base“ refererer til giveren, som i $-n d a ?^{3} a ?^{2}-l i^{3}$, ,at bede om noget som ikke tilhører én selv" versus - 
$n d a ?^{2} a^{I}$, at bede om noget som tilhører én selv“". Derimod er den implicitte bevægelse i ,at modtage“ " $i l$ modtageren idet ,base“" her refererer til modtagerens locus: - $g u^{2} r i^{2} g u^{l}-l i^{3}$ ,at modtage noget der tilhører én selv“" versus - $g u^{3} r i^{3} g w i^{1}$, ,at modtage noget der ikke tilhører én selv“". For at knytte tilbage til eksemplet med bønnesuppen der faldt på gulvet, så ville den akt hvorved tallerkenen samles op på tlapanec beskrives med verbet $-k u^{2} \breve{s} i^{l}$ $\cdot l i^{3}$,,at løfte noget op igen (til dens base på bordet) “, mens - $k u^{3} \breve{s}^{l}{ }^{l}$ ville beskrive en akt som at løfte bordet op fra gulvet - altså til en non-base i luften.

Den menneskelige krop udgør også en topologi, for -? $\eta a^{2} h \eta o{ }^{1}$ ville bruges om at synke en bid mad (væk fra kilden det være sig plante eller dyr), mens -? $\eta a^{2} h \eta g o^{I}-l i^{3}$ ville bruges om at synke en spytklat (til dens kilde et eller andet sted i kroppen).

Selv tanker har retning og sted, for et verbum som $-k u^{3} m a^{I}-l i^{3}$, at tænke tilbage, være nostalgisk" koder for "base“ "mens $-k u^{2} m u^{l}$, ,at tænke (for eksempel udpønse en plan)“ koder for ,non-base“. Ømt at erindre en kvinde man har elsket ville kunne udtrykkes ved følgende metafor:

$$
\begin{array}{llll}
\text { nima } \text { ? }^{2} a^{l} \text { ?la }^{3} & a^{2} h k y o n^{32} & k a ?^{2} y o^{l} & a ?^{2} g u^{3} \\
\text { placere_sig } & \text { hans_hjerte } & \text { PRÆPP } & \text { kvinde }
\end{array}
$$

„han erindrede hende“ (ordret: „,hans hjerte placerede sig ved kvinden (dets base)“

(Ordet $k a ?^{2} y o^{l}$ der her, i mangel af bedre, er glosseret som en PRÆPosition og frit oversat som ,ved“ kan egentlig ikke oversættes fordi det er et rent grammatisk ord som har den eneste funktion at introducere det, man traditionelt kalder indirekte objekter, for en lille gruppe af verber, der ofte udtrykker følelsesforhold eller på anden måde komplekse forhold mellem mennesker).

Som allerede antydet er det med hensyn til verber der koder for base-kategorien, objektet for det transitive verbum eller subjektet for det intransitive verbum hvis perspektiv udtrykkes. Med en litteraturteoretisk metafor kan man sige at verbalsemantikken gør brug af dækket direkte tale (oratio tecta). Disse objekter eller subjekter ,"taler“" om deres tilhørsforhold. Dette er intetsteds så tydeligt som i forbindelse med verbet , ,at se op“. Som et eksempel på brugen af den iterative afledning, forklarede en informant mig at hvis et egern sidder og ser op ad en træstamme mod sit hul, så ville man bruge iterativen. Non-iterativen ville for eksempel kunne bruges om et egern der kiggede op på en forbiflyvende fugl.

Op til nu har jeg samlet eksempler med henblik på at vise hvordan adækvat sprogbrug er uløseligt forbundet med en kulturelt nedarvet viden om verdens indretning. Forskellige sprog tilbyder forskellige valg. Når danskere udtaler sig om placeringen af genstande eller personer i hjemmet har de begrænsede udtryksmuligheder svarende til en karakteristisk kulturel topologi. Hopier og yukatekiske mayaer har andre udtryksmuligheder, der er domineret af rumdeiksis. I tlapanec er den overordnede kategori ,hjemlighed", ,habituelt spatielt tilhørsforhold“ eller - kortere - „,base“ gennemgribende for konceptualiseringen af bevægelse.

\section{Sprog og rum som forskningsfelt}

Jeg har i det foregående forsøgt at vise hvordan overvejelser over forholdet mellem sprog og rumlig orientering i livsverdenen kan starte med nogle relativt simple iagttagelser, 
hvilke jeg har søgt at anskueliggøre med konkrete, til dels originale eksempler. For fremstillingens skyld har jeg været tematisk selektiv og holdt mig til det domestiske rum og har i øvrigt begrænset mig sprogligt-geografisk til de områder, jeg er bedst bekendt med. Jeg vil nu forsøge at aftegne de bredere konturer for emnet „sprog og rum" og i denne forbindelse forsøge at formidle et indtryk af, hvilken slags forskning der er foretaget på området.

Interessen for ,hvordan sprog strukturerer rum“ (for at alludere til en central artikel af Talmy (1983)) slog først igennem et stykke inde i 1980’erne. Tidligere arbejder inden for området omhandler mest emner som deiksis eller præpositioner, emner der per se har med sprog og rum at gøre (Clark 1978; Fillmore 1975; Anderson \& Keenan 1985; Friedrich 1969; Denny 1982). Disse arbejder er dataorienterede og mest kun ad hoc-teoretiske. Men området fik et teoretisk fundament i kraft af især Talmys (1983) og Langackers (1987-1990) studier som forsøger at lade konceptualiseringen af rummet levere de centrale begreber for semantikken i det hele taget. I kølvandet på denne såkaldt kognitive semantik er flere antropologiske lingvister begyndt at interessere sig for forholdet mellem sprog og rum - men ud fra et mindre universaliserende og mere empirisk synspunkt. Igen er der aner at finde, men de er få og spredte (Whorf 1956; Berlin 1968). Levinson (1991) legitimerer den nyere antropologisk-lingvistiske interesse for sprog og rum delvis som en reaktion mod den tendens til at overgeneralisere der stammer fra de kognitive videnskabers alt for klippefaste tro på at de vigtigste aspekter af den menneskelige kognition er medfødte. Hertil bemærker han at ,kognitiseringen af rum har været en af de foretrukne slagmarker for stridende erkendelsesforståelser i filosofi og psykologi; rumbegreber forekommer på en gang at være for abstrakte til at kunne udledes af erfaringen og dog samtidigt immanente i den fysiske verden vi må lære at begå os i. Derfor forbliver rumopfattelsen et frugtbart område hvis man vil gentænke hele forholdet mellem de biologisk og kulturelt givne færdigheder i den menneskelige tænkning" (Levinson 1991:34). Overvindelsen af modsætningen mellem kultur og natur som epistemologiske poler inden for området (en gammel modsætning, jf. Hatfield 1990) er endnu et uafsluttet projekt. På den ene side producerer de kognitive semantikere modeller der får os til at se på sprog på en ny måde, men som er designet så de er umulige at falsificere, og på den anden side producerer de antropologiske lingvister en mængde ny viden, men her er der ofte tale om viden som er svær at integrere teoretisk. Hvad den sidstnævnte tendens angår kan nævnes forsøget fra Lucy (1992a) på at omformulere Sapir-Whorf-hypotesen om det kausale forhold mellem sprog og tænkning i blødere vendinger, et projekt der dog mislykkes fordi hans konkrete eksperimenter (Lucy 1992b) ikke følger logisk af hans redegørelse for de pågældende sprogs semantik (engelsk over for yukatekisk maya) og i øvrigt svigter rent teknisk (Wichmann 1993c). Man kan også nævne Hanks' femtenårige studium af deiksis i yukatekisk maya (1990; berørt ovenfor) som svigter for så vidt som det ikke udmønter sig i en integration af andre sproglige aspekter (Wichmann 1993b).

Der har været forskellige studier af hvordan sprog udtrykker retning, position og form. Fra beskrivelser hos England (1976a, 1976b, 1978, 1983) kan man få et præcist indblik i hvor gennemgående retningudtryk kan være indvævet i et grammatisk system. I det pågældende sprog, nemlig maya-sproget mam, kan man ganske enkelt ikke udtrykke en handling som involverer mere en én aktant uden også at udtrykke en retning for handlingen. Hvad angår arter af retning, har Haviland beskrevet (1986) hvorledes det australske sprog guugu yimidhirr benytter sig af absolutte akser - lidt svarende til vores kompasretninger - i sine udtryk for retning (se også Haviland 1979). Heroverfor er der mange 
mesoamerikanske (for eksempel MacLaury 1989), oceaniske (Bowden 1991) og afrikanske (Heine 1989) sprog der benytter sig af kroppens topologi som grundlag for retningsangivelse. I tlapanec (omtalt ovenfor), der også er et eksempel herpå, er for eksempel „foran den“" = ,dens ansigt" og ,bag den“ = ,dens ryg“. Systemer så som vores venstrehøjre-akse er endnu et eksempel på en mulig - men ikke en universel - måde at udtrykke retning på.

I studier af position og form kan man blandt andet fremhæve studier af engelske præpositioner (Herskovits 1986), tyske dimensionsadjektiver (Lang et al. 1991) og arbejdet med den sproglige beskrivelse af position på tzotzil (de León 1991).

Mens vi nyder at se hvordan forskellige resultater inden for studierne af kognition og kultur fortsat akkumuleres kan vi håbe på at „og'et“" virkelig efterhånden antager den værdi af konjunktion som det giver sig ud for at have. Men hvis studierne ignorerer de livsverdener som talerne tilhører og glemmer at sprog er produkter af en social handlen, vil kultur og kognition forblive disjunktive størrelser og vores erkendelser om dem tilsvarende desintegrerede.

\section{Afslutning}

Sprog og praksis er uadskillelige størrelser. Det viser sig i forskellig grad i forbindelse med forskellige typer grammatiske kategorier. Et område, hvor det tydeligt viser sig, er i forbindelse med den sproglige konceptualisering af rum. Den videre udforskning af dette område stiller store krav til integrationen af metodologi og teori inden for lingvistik og antropologi, men de teoretiske modeller som kan hjælpe os i en evaluering af hvad vi kan stille op med vore indsigter, må fortsat, i sidste ende, lade sig fodre af en åbenhed og nysgerrighed over for og en registrering af brugen af sproglige udtryk for rumlige fænomener $\mathrm{i}$ de mest dagligdags og netop derfor mest uhåndgribelige situationer - både $\mathrm{i}$ vores egen og i andre kulturer.

\section{Litteratur}

Anderson, Stephen \& Edward Keenan

1985 Deixis. I: Timothy Shopen (ed.): Language Typology and Syntactic Description.

Cambridge: Cambridge University Press:259-308.

Berlin, Brent

1968 Tzeltal Numeral Classifiers. Berkeley: University of California Press.

Bowden, J.

1991 Grammaticalization of Locatives in Oceanic Languages. MA thesis, University of Auckland.

Clark, Eve

$1978 \quad$ Locationals: Existential, Locative and Possessive Constructions.

I: Joseph Greenberg (ed.): Universals of Language 4:85-126.

de León, Lourdes

1991 Space Games in Tzotzil: Creating a Context for Spatial Reference. Working Paper 4.

Nijmegen: Cognitive Anthropology Research Group. 
Denny, J. Peter

1982 Semantics of the Inuktitut (Eskimo) Spatial Deixis. International Journal of American Linguistics 48: 359-84.

England, Nora C.

1976a Mam Directionals and Verb Semantics. I: McClaran (ed.): Mayan linguistics 1. Los Angeles: American Indian Studies Center. 202-11.

1976b Verb Categories in Mam. Florida Journal of Anthropology 1(2):1-8.

1978 Space as a Mam Grammatical Theme. I: Nora C., England (ed.): Papers in Mayan Lingustics Columbia: Dept. of Anthropology, University of Missouri-Colombia, 225-38. (University of Missouri Miscellaneous Publications in Anthropology 6; Studies in Mayan Linguistics 2).

Fillmore, Charles

1975 Santa Cruz Lectures on Deixis. Indiana University Linguistics Club. (Fotokopi).

Friedrich, Paul

1969 On the Meaning of the Tarascan Suffixes of Space. Memoir 23. Indiana University

Publications in Anthropology and Linguistics.

Goffman, Erwin

1981 Forms of Talk. Philadelphia: University of Pennsylvania Press.

Hanks, William, F.

1990 Referential Practice. Language and Lived Space among the Maya. Chicago \& London: The University of Chicago Press.

Hatfield, G.

1990 The Natural and the Normative: Theories of Spatial Perception from Kant to Helmholtz. Cambridge, Mass.: MIT Press.

Haviland, John B.

1979 Guugu Yimidhirr: Sketch Grammar. I: R. M. W. Dixon \& Barry Blake (eds.):

Handbook of Australian Languages 1:25-180.

1986 Complex Referential Gestures in Guugu Yimidhirr. Manuskript.

Heine, Bernd

1989 Adpositions in African Languages. Linguistique Africaine:77-127.

Herskovits, Anette

1986 Language and Spatial Cognition: An Interdisciplinary Study of Prepositions in English.

Cambridge: Cambridge University Press.

Kuiper, Albertha \& William R. Merrifield

1975 Diuxi Mixtec Verbs of Motion and Arrival. International Journal of American Linguistics 41:32-45.

Lang, Ewald, Kai-Uwe Carstensen \& Geoffrey Simons

$1991 \quad$ Modelling Spatial Knowledge on a Linguistic Basis. Theory - Prototype - Integration (Lecture Notes in Artificial Intelligence:481). Berlin: Springer-Verlag.

Langacker, Ronald

1987-1990 Foundations of Cognitive Grammar 1-2. Stanford, California: Stanford University Press.

Levinson, Stephen C.

1991 Primer for the Field Investigation of Spatial Description and Conception. Working Paper 5. Nijmegen: Cognitive Anthropology Research Group.

Lucy, John A

$1992 \mathrm{a}$

Language Diversity and Thought. A Reformulation of the Linguistic Relativity Hypothesis.

(Studies in the Social and Cultural Foundations of Language 12).

Cambridge: Cambridge University Press.

Lucy, John A

$1992 \mathrm{~b}$

Grammatical Categories and Cognition. A Case Study of the Linguistic Relativity Hypothesis (Studies in the Social and Cultural Foundations of Language 13).

Cambridge: Cambridge University Press. 
MacLaury, R.

1989 Zapotec Body-part Locatives: Prototypes and Metaphoric Extensions. International Journal of American Linguistics 55:119-54.

Malotki, Ekkehart

1979 Hopi-Raum. Eine sprachwissenschaftliche Analyse der Raumvorstellungen in der HopiSprache (Tübinger Beiträge zur Linguistik 81). Tübingen: Gunter Narr Verlag.

Merrifield, William R.

1992 Concerning Otomanguean Verbs of Motion. I: Shin Ja J. Hwang \& William R. Merrifield (eds.): Language in Context: Essays for Robert E. Longacre. Austin: University of Texas at Austin/Summer Institute of Linguistics. 475-97.

Talmy, Leonard

1983 How Language Structures Space. I: H. Pick \& L. Acredolo (eds.): Spatial Orientation:

Theory, Research and Application. New York: Plenum Press. 225-320.

Whorf, Benjamin Lee

1956 Language,Thought, and Reality. Selected Writings of Benjamin Lee Whorf.

John B. Carroll (ed.). Cambridge, Mass.: MIT Press.

Wichmann, Søren

1992 A Semantic Framework for the Azoyú Tlapanec Iterative.

Acta Linguistica Hafniensia 25:125-42.

1993a Spatial deixis in Azoyú Tlapanec. Sprachtypologie und Universalienforschung 2:113-32.

1993b Review of Hanks (1990). Journal of Pragmatics 20:291-300.

1993c Review of Lucy (1992a-b). Social Anthropology - Anthropologie Sociale 1:358-60. 
